\title{
Penelitian Genom dan Implikasinya dalam Kesehatan Masyarakat di Indonesia
}

\author{
Genome Research and Its Implication in Public Health in Indonesia
}

\author{
Doni Hikmat Ramdhan
}

\section{Departemen Keselamatan dan Kesehatan Kerja Fakultas Kesehatan Masyarakat Universitas Indonesia}

\begin{abstract}
Abstrak
Penelitian genom yang mengkaji kaitan antara setiap gen dengan suatu penyakit sekaligus mekanismenya untuk mendapatkan pengetahuan yang menyeluruh dalam pengobatan, telah membawa perubahan besar dunia kedokteran dalam mengobati berbagai penyakit. Namun demikian, penelitian genom seharusnya tidak hanya dimanfaatkan untuk pengobatan tetapi juga untuk pencegahan penyakit. Artikel ini membahas masalah kesehatan masyarakat dan peluang pemanfaatan penelitian genom dalam pencegahan penyakit. Penelitian genom yang dapat dimanfaatkan pada bidang kesehatan masyarakat adalah toksikogenomik dan nutrigenomik. Penelitian toksikogenomik mengkaji respons gen akibat pajanan toksikan yang berdampak pada kesehatan manusia. Penelitian nutrigenomik mengkaji respons gen terhadap makanan yang berdampak pada kesehatan manusia. Penelitian toksikogenomik dan nutrigenomik dapat mengungkap mekanisme molekuler suatu penyakit. Selanjutnya, pada gen yang mengalami perubahan ekspresi dapat dijadikan target molekuler untuk pencegahan. Dengan demikian, perkembangan penelitian genom memberikan tantangan bagi pengembangan ilmu kesehatan masyarakat untuk dalam pencegahan penyakit.
\end{abstract}

Kata kunci: Genom, kesehatan masyarakat, nutrigenomik, toksikogenomik

\footnotetext{
Abstract

Genome research which examines association of each gene with a disease and its mechanism to explore comprehensive knowledge in disease treatment, has brought about great changes in medicine in the treatment of diseases. However, genomic research should not only be applied in treatment but also in disease prevention. This article discusses public health problems and opportunities of genomic research application in disease prevention. Genome research that can be utilized in the field of public health is toxicogenomics and nutrigenomics. Research toxicogenomics investigate gene responses due to exposure to the toxicant that impact on human health. Nutrigenomics research examines gene response to food that affect to hu-
}

man health. Toxicogenomics and nutrigenomics research can uncover the molecular mechanisms of disease. Furthermore, the gene expression changes that may be used as molecular targets for prevention. Thus, the development of genome research provides a challenge for the development of public health sciences to be used in the prevention of disease. Keywords: Genome, public health, nutrigenomic, toxicogenomic

\section{Pendahuluan}

Penelitian genom manusia yang bertujuan untuk memetakan dan mengidentifikasi seluruh DNA manusia telah dimulai tahun 1990 dan baru berakhir tahun 2003. Keberhasilan memetakan dan mengidentifikasi seluruh gen manusia, yang berjumlah sekitar 30.000, telah memberikan manfaat kepada bidang kedokteran untuk pengobatan dan diagnosis penyakit yang didasarkan pada kondisi genetiknya. Pemetaan gen telah dimanfaatkan untuk memprediksi gangguan kesehatan yang diderita dan pengobatan berbagai penyakit keturunan, seperti cystic fibrosis dan hemophilia. ${ }^{1}$ Selain pada aspek pengobatan penyakit, pemetaan gen manusia ditantang untuk dapat dimanfaatkan di bidang kesehatan masyarakat. Pemetaan gen seharusnya tidak hanya fokus pada penyakit keturunan seperti yang disebutkan sebelumnya tetapi dapat dimanfaatkan pada masalah penyakit yang lebih luas. Pemetaan informasi gen manusia seharusnya bisa digunakan untuk menggali metode-metode pencegahan penyakit menular maupun tidak menular (degeneratif).

Korespondensi: Doni Hikmat Ramdhan, Departemen Keselamatan dan Kesehatan Kerja, Gd. C Lt. 1 FKM Universitas Indonesia, Kampus Baru UI Depok 16424, Hp.085697968639,e-mail: doni@ui.ac.id 
Di Indonesia, saat ini permasalahan di bidang kesehatan masyarakat sudah semakin kompleks. Ketika penyakit menular belum sepenuhnya berhasil diberantas secara tuntas, muncul masalah baru yaitu penyakit tidak menular. Penyakit tidak menular muncul seiring dengan semakin berkembangnya kehidupan sosial ekonomi masyarakat yang telah berdampak pada perubahan lingkungan dan gaya hidup. Seiring dengan berkurangnya lahan pemukiman di daerah perkotaan, semakin banyak penduduk yang tinggal dekat dengan industri yang mengolah dan menghasilkan toksikan sebagai bahan baku dan produk. Apabila pihak perusahaan tidak mengelola toksikan dengan tepat akan menimbulkan pajanan terhadap pekerja dan masyarakat sekitar sehingga menimbulkan gangguan kesehatan. Umumnya penyakit yang ditimbulkan merupakan penyakit tidak menular seperti silikosis, asbestosis, iritasi kulit, gangguan saluran pernapasan. Dilaporkan misalnya, anak laki-laki di Jawa Barat berusia $10-12$ tahun yang tinggal di wilayah industri mempunyai risiko 1,9 kali terkena gangguan fungsi paru dibandingkan dengan anak laki-laki yang tinggal di wilayah bukan industri. ${ }^{2}$ Selain itu, dengan semakin meningkatnya daya beli, pola konsumsi makanan berimbang pada masyarakat perkotaan telah semakin berubah. Untuk mencegah penyakit yang berkaitan dengan perubahan gaya hidup dan lingkungan, maka diperlukan upayaupaya pencegahan yang didasarkan pada hasil riset yang baik dan mutakhir.

Sehubungan dengan pesatnya perkembangan penelitian genom dan kompleksitas permasalahan kesehatan masyarakat, artikel ini membahas peluang pemanfaatan penelitian genom di bidang kesehatan masyarakat. Tulisan ini merupakan jawaban atas undangan Direktorat Penelitian dan Pengabdian Masyarakat Universitas Indonesia (DRPM UI) untuk menelaah dan mengkaji ulang arah pengembangan penelitian genom sebagai salah satu bidang unggulan penelitian UI. Telaahan ini merupakan salah satu sumbangan pemikiran dalam menentukan arah pengembangan keilmuan dan penelitian di Fakultas Kesehatan Masyarakat Universitas Indonesia (FKM UI). Keilmuan yang dikembangkan diharapkan dapat menjawab berbagai permasalahan yang ada pada bidang kesehatan masyarakat saat ini dan mendatang, sehingga FKM UI sebagai lembaga pendidikan dan penelitian dapat memberikan kontribusi sebesar-besarnya dalam meningkatkan kesejahteraan bangsa.

\section{Pemanfaatan Penelitian Genom \\ Pohon Pengembangan Penelitian Genom di UI}

Pada tahun 2007, DRPM UI telah menetapkan penelitian genom dan proteinomik untuk kesehatan perkotaan sebagai salah satu bidang riset unggulan UI. ${ }^{3}$ Penelitian genom dan proteinomik untuk kesehatan perkotaan terdiri dari tiga bidang, yaitu penyakit menu- lar, penyakit degeneratif, dan kajian genomik lokal. Penelitian pada tiga aspek ini bertujuan untuk menghasilkan rekomendasi ilmiah dan penemuan metode terapi untuk pencegahan dan pengobatan penduduk perkotaan secara tuntas untuk penyakit menular maupun penyakit degeneratif.

Berdasarkan pohon pengembangan tersebut, arah penelitian genom lebih ditujukan pada aspek penyakit hereditas (keturunan). Pada sub bidang epidemiologi molekuler, penelitian difokuskan pada identifikasi peran variasi genetik sebagai faktor risiko penyakit dan sebagai penanda tingkat risiko penyakit. Perbedaan variasi genetika membuat beberapa orang lebih rentan dan lainnya lebih tahan terhadap agen penyakit. Melalui pendekatan ini, skrining yang dilakukan pada usia muda sangat penting untuk mendeteksi seseorang atau sekelompok masyarakat yang mempunyai riwayat keluarga menderita suatu penyakit terkait genetik. Dengan mengetahui tingkat risiko penyakit, orang tersebut bisa dikategorikan pada kelompok yang berisiko tinggi, sedang, atau rendah. Pengelompokan tingkat risiko ini dapat mempermudah upaya-upaya pencegahan dan intervensi melalui pemilihan strategi yang tepat dan sesuai kebutuhan.

Pada periode awal, penelitian genom lebih banyak dipakai untuk mengungkap masalah penyakit hereditas melalui identifikasi variasi genetik antar individu (polimorfisme) dikaitkan dengan munculnya penyakit keturunan pada kelompok tertentu. Informasi variasi genetik tersebut selanjutnya digunakan untuk mendeteksi dan mengidentifikasi orang atau kelompok berisiko terhadap suatu penyakit sehingga sangat membantu dalam pencegahan dan penanganan beberapa penyakit tertentu. Kenyataannya, penyakit yang muncul di masyarakat perkotaan tidak hanya penyakit klasik menular atau terkait kelainan genetik, tetapi juga penyakit tidak menular seperti penyakit jantung koroner, kanker, dan diabetes yang hampir 80 - 90\% tidak berkaitan dengan faktor kelainan genetik. ${ }^{4}$ Determinan penyakit ini lebih berkaitan dengan perilaku seseorang seperti merokok, pola makan, kurangnya aktivitas fisik atau buruknya kualitas lingkungan di perkotaan akibat pencemaran udara dan air yang berasal dari aktivitas industri dan gas buang sarana transportasi.

\section{Pengembangan Penelitian Genom Bidang Kesehatan Masyarakat}

Setiap hari masyarakat perkotaan tidak hanya terpajan pencemar udara yang berasal dari emisi gas buang kawasan industri tetapi juga dari gas buang kendaraan bermotor. Minimnya ketersediaan sarana transportasi massal, penggunaan kendaraan angkutan pribadi seperti mobil dan sepeda motor terus meningkat. Hal ini dapat memperparah pencemaran udara. Hingga saat ini, emisi 
gas buang dari kendaraan bermotor telah menjadi sumber pencemaran udara utama di perkotaan.

Di jalan raya telah diidentifikasi berbagai jenis pencemar udara sebagai berikut emisi partikulat, hidrokarbon, okida belerang dan nitrogen $\left(\mathrm{SO}_{\mathrm{x}}\right.$ dan $\left.\mathrm{NO}_{\mathrm{x}}\right)$. Emisi partikulat dari mesin kendaraan bermotor merupakan kontributor utama $(51-69 \%)$ terhadap pencemaran udara di perkotaan. ${ }^{5}$ Banyak penelitian melaporkan adanya efek kesehatan yang ditimbulkan oleh pajanan partikulat seperti ganguan fungsi paru, asma, chronic obstructive pulmonary disease (COPD atau penyakit paru obstruksi kronik, PPOK), dan efek kesehatan yang relatif baru diteliti secara saksama adalah penyakit diabetes melitus, arteriosklerosis, dan stroke.6,7

Terkait dengan efek kesehatan oleh pajanan partikulat, dari penelitian kami sebelumnya melalui uji coba tikus jantan Fischer 344 diketahui bahwa partikulat berukuran nanometer yang berasal dari buangan mesin diesel dapat menyebabkan gangguan fungsi reproduksi berupa peningkatan kadar hormon testosteron pada kelompok pajanan rendah $\left(15 \mu \mathrm{g} / \mathrm{m}^{3}\right)$ dan sedang (36 $\mu \mathrm{g} / \mathrm{m}^{3}$ ) dibandingkan dengan kadar testosteron kelompok kontrol. ${ }^{8}$ Peningkatan kadar testosteron tersebut beriringan dengan peningkatan ekspresi mRNA dan protein cytochrome P450 2A11 (CYP2A11) dan steroidogenic acute regulatory (StAR).

Selain pencemaran udara, pencemaran air minum merupakan salah satu masalah kesehatan masyarakat paling serius di negara berkembang seperti Indonesia. Pencemaran air minum biasanya terjadi karena sumber air baku atau sarana pengolahan air terkontaminasi oleh mikroorganisme (virus, bakteri patogen, parasit) atau senyawa kimia. Di Indonesia, banyak aliran sungai atau danau yang menjadi tempat pembuangan limbah cair hasil kegiatan industri dan rumah tangga. Efek kesehatan akibat konsumsi air yang terkontaminasi mikroorganisme dapat timbul secara akut, misalnya diare. Akan tetapi, pada air yang tercemar oleh bahan kimia, efek kesehatan akan muncul dalam waktu yang relatif lama akibat pajanan dengan dosis rendah tetapi terus menerus. Pada pencemaran seperti ini, efek kesehatan yang timbul sering tidak spesifik dan sulit dideteksi.

Air minum yang sudah tercemar logam berat dapat menyebabkan beberapa penyakit seperti gangguan syaraf, gagal ginjal, gangguan imun tubuh dan kanker kulit. Seperti yang dilaporkan sebelumnya, terdapat hubungan yang signifikan antara tingkat arsenik dan barium pada air minum yang dikonsumsi dengan tingkat elemen kimia tersebut pada urine, kuku dan rambut responden. ${ }^{9}$ Penelitian lain menunjukan bahwa terjadi peningkatan kejadian kanker kulit di Bangladesh karena banyaknya penduduk yang mengonsumsi air minum yang tercemar arsenik. ${ }^{10}$

Polutan atau senyawa kimia, yang telah diabsorpsi pa- da saluran pernafasan, pencernaan maupun kulit melalui mekanisme pasif maupun aktif, akan didistribusikan ke seluruh tubuh oleh sistem peredaran darah. Polutan ini mengalami dua fase biotransformasi di dalam hati. Fase I meliputi hidrolisis, reduksi, dan oksidasi dengan bantuan enzim famili P450 dan fase II meliputi glukuronidasi, asetilasi, dan konjugasi oleh enzim glutatione S-transferase sehingga senyawaan tersebut menjadi lebih polar dan hidrofilik. ${ }^{11}$ Setelah ditransformasi, senyawaan kimia berubah menjadi metabolit yang mudah disekresikan melalui urine, feses (tinja), dan keringat. Senyawaan kimia yang diabsorpsi tubuh dapat berikatan dengan molekuler tubuh seperti membran sel, inti sel yang berisi DNA atau protein yang berupa reseptor membran, reseptor intraseluler, dan enzim. Hasil ikatan ini dapat menyebabkan sejumlah perubahan biokimia pada molekul target dan menyebabkan tidak berfungsinya molekul tersebut karena gangguan transkripsi ataupun translasi DNA, aktivasi atau inhibisi molekul. Efek lainnya adalah kerusakan molekul akibat terganggunya lingkungan mikro dalam sel. Tidak berfungsinya ataupun rusaknya molekul tersebut selanjutnya dapat menyebabkan tidak berfungsinya organel sel dan kerusakan sel (nekrosis), kerusakan jaringan, dan kerusakan organ, yang selanjutnya memicu munculnya penyakit.

Dewasa ini permasalahan kesehatan perkotaan juga diperparah oleh perubahan pola hidup seperti buruknya pola makan dan rendahnya olahraga atau aktivitas fisik. Perilaku masyarakat perkotaan yang lebih menyukai makanan cepat saji (fast food) yang mempunyai kadar lemak dan asam lemak trans yang tinggi dari hasil proses penggorengan telah menyebabkan peningkatan angka obesitas dan risiko penyakit jantung. Asam lemak trans dalam tubuh dapat meningkatkan kadar low-density lipoprotein (LDL) dan menurunkan kadar high-density lipoprotein (HDL), penumpukan LDL pada dinding pembuluh darah dapat menimbulkan aterosklerosis, sementara penurunan kadar HDL menghambat metabolisme lemak dan kolesterol sehingga menimbulkan obsesitas. Bertambahnya berat badan dan penumpukan lemak pada area perut pada penderita obesitas merupakan predisposisi resistensi insulin, dislipidemia, hipertensi, dan kondisi inflamasi, yang selanjutnya sangat berdampak pada perkembangan penyakit jantung aterosklerosis dan diabetes melitus tipe $2 .{ }^{12}$

Pada penelitian eksperimen binatang, dilaporkan bahwa asupan asam lemak trans menyebabkan akumulasi trigliserida dan total kolesterol di hati yang disertai dengan obesitas dan peningkatan kadar kolesterol darah. ${ }^{13}$ Penelitian lain menemukan bahwa pada kelompok wanita yang mengonsumsi makanan mengandung asam lemak trans, terjadi penurunan kadar HDL dan peningkatan kadar LDL. ${ }^{14}$ Metabolisme asam lemak pada hati biasanya melalui jalur metabolisme yang meli- 
batkan peroxisome proliferator activated reseptors (PPARs). Di bidang biologi molekuler, PPARs yang terdiri dari PPARa, g, b/d merupakan protein reseptor pada inti sel yang berfungsi sebagai faktor transkripsi yang mengatur ekspresi gen, berperan penting dalam regulasi seluler, diferensiasi sel, dan metabolisme (karbohidrat, lipid, protein), dan tumorigenesis dari sistem organisme tingkat tinggi. ${ }^{15}$ Pada hati, dibandingkan dengan jenis lainnya, tingkat ekspresi PPARa adalah yang paling tinggi hal ini berkaitan dengan peran PPARa yang paling dominan, yaitu memetabolisme asam lemak melalui jalur b-oksidasi sehingga tidak terjadi penumpukan lemak di hati. ${ }^{16}$

Penyakit akibat pajanan polutan (toksikan) lingkungan ataupun tempat kerja sebenarnya dapat dicegah dengan menghilangkan, mengganti, atau menurunkan konsentrasi toksikan melalui rekayasa pengembangan teknologi. Pengendalian ini tidak sepenuhnya dapat menurunkan konsentrasi emisi polutan ke kadar yang sangat rendah, apalagi menghilangkannya. Sebagai contoh, pada awalnya filter yang dipasang pada knalpot kendaraan bermotor dapat menyaring partikulat agar kadar emisinya rendah. Namun, pengembangan teknologi pengendalian tersebut melupakan dimensi ukuran partikulat yang berskala nano sampai mikrometer. Filter yang dipasang pada knalpot hanya mampu menyaring partikulat ukuran besar sehingga partikulat berukuran kurang dari 2,5 mikrometer dapat lolos keluar knalpot dan kadar emisinya menjadi lebih tinggi. ${ }^{17}$ Selanjutnya, walaupun masalah penyakit kronis dapat dicegah dengan melakukan manipulasi lingkungan, pendekatan pencegahan kesehatan masyarakat belum sepenuhnya berhasil. Sebagai contoh, masih banyak masyarakat yang aktivitas fisik dan pola konsumsi makannya tidak berimbang. Menurut Riset Kesehatan Dasar (Riskesdas) tahun 2010, prevalensi obesitas menunjukkan angka yang cukup mengkhawatirkan. Berdasarkan survei yang dilakukan pada tahun 2010, prevalensi nasional penduduk berusia $\geq 18$ tahun dengan indeks massa tubuh (IMT) 25 mencapai $21,7 \%$, terdiri dari laki-laki $16,3 \%$, dan perempuan $26,9 \% .18$

Penelitian genom di bidang kesehatan masyarakat terkait penyakit yang faktor risikonya adalah faktor lingkungan seharusnya dapat mengungkap bagaimana pajanan bahan berbahaya dari lingkungan dapat berefek pada ekspresi gen dan protein. Dengan demikian, penelitian genom pada bidang kesehatan masyarakat dapat dikembangkan dan dikenal dengan istilah toksikogenomik, yang mengkaji ekspresi gen dan protein akibat pajanan faktor lingkungan, dan nutrigenomik, yang mengkaji efek dari konsumsi makanan terhadap ekspresi gen dan protein. ${ }^{19}$

Selanjutnya, meskipun faktor pajanan lingkungan mempunyai peranan yang sangat penting dalam hampir semua penyakit, faktor ini sangat sulit ditentukan sebagai penyebab penyakit. Pada periode pajanan, seseorang terpajan dengan faktor lingkungan sering tidak dalam keadaan konstan, tetapi berubah-ubah sepanjang waktu, misalnya pada faktor asupan makanan atau pajanan pencemar udara. Selain itu, adanya kesulitan mengukur tingkat pajanan secara akurat dan ketidakberhasilan mengukur kadar pajanan pada konsentrasi yang rendah, menyebabkan kita sering menyepelekan, menyampingkan, dan mengabaikan bahaya interaksi faktor lingkungan dan gen yang menimbulkan penyakit. Untuk hal ini, perlu dikembangkan lagi bagaimana penelitian genomik di bidang kesehatan masyarakat mampu mengembangkan suatu metode yang lebih baik lagi untuk bisa mengukur tingkat pajanan faktor lingkungan.

Penemuan biomarker pada tahap pajanan menjadi hal sangat penting dalam bidang kesehatan masyarakat. Biomarker ini dapat dikembangkan dari kajian terhadap ekspresi gen, dalam hal ini mRNA, cDNA, dan protein. Mengkaji ekpresi gen akan memperkaya dalam memahami pengaruh senyawaan kimia dan agen lingkungan lainya terhadap timbulnya penyakit. Pengetahuan terhadap biomarker tersebut akan mempermudah dalam mendeteksi secara dini sehingga program pencegahan akan lebih efektif dan selektif. Selain itu, penelitian toksikogenomik dan nutrigenomik akan membuka kajian terhadap suatu biomarker molekuler untuk dijadikan target molekuler pencegahan. Misalnya, pemberian ekstrak teh hijau telah digunakan untuk meningkatkan aktivitas enzim antioksidan superoxide dismutase dalam mencegah penyakit serangan jantung akut. ${ }^{20}$

\section{Kesimpulan}

Kemajuan dalam penelitian genom dan kompleksnya masalah kesehatan telah menuntut penelitian bidang kesehatan masyarakat untuk lebih responsif dan antisipatif. Pengembangan penelitian di bidang toksikogenomik dan nutrigenomik dapat menjadi salah satu jawaban terhadap permasalahan kesehatan masyarakat dewasa ini.

\section{Daftar Pustaka}

1. Bell J. Predicting disease using genomics. Nature. 2004; 429: 453-6.

2. Salami IR, As ZA, Marselina M, Roosmini D. Respiratory health risk assessment of children living close to industrial areas in Indonesia. Reviews on Environmental Health. 2014; 29 (1-2):139-42.

3. Direktorat Riset dan Pengabdian Masyarakat Universitas Indonesia. Priority research tree University of Indonesia. Depok: Universitas Indonesia; 2007.

4. Cooper RS, Psaty BM. Genomics and medicine: distraction, incremental progress or the dawn of a new age. Annals of Internal Medicine Journal. 2003; 138: 576-80.

5. Kittelson DB. Engines and nanoparticles: a review. Journal of Aerosol Science. 1998; 29: 575-88.

6. Garshick E, Laden F, Hart JE, Rosner B, Smith TJ, Dockery DW, et al. 
Lung cancer in railroad workers exposed to diesel exhaust. Environmental Health Perspectives. 2004; 112: 1539-43.

7. Pope CA, Dockery DW. Health effects of fine particulate air pollution: lines that connect. Journal of the Air and Waste Management Association. 2006; 56 (6): 709-42.

8. Ramdhan DH, Ito Y, Yanagiba Y, Yamagishi N, Hayashi Y, Li C, et al. Nanoparticle-rich diesel exhaust may disrupt testosterone biosynthesis and metabolism via growth hormone. Toxicology Letters. 2009; 191 (23): 103-8.

9. Kato M, Kumasaka MY, Ohnuma S, Furuta A, Kato Y, Shekhar HU, et al. Comparison of barium and arsenic concentrations in well drinking water and in human body samples and a novel remediation system for these elements in well drinking water. PLOS One. 2013; 8 (6).

10. Kumasaka MY, Yamanoshita O, Shimizu S, Ohnuma S, Furuta A, Yajima I, et al. Enhanced carinogenicity by coexposure to arsenic and iron and a novel remediation system for the elements in well drinking water. Archives of Toxicology. 2013; 87 (3): 439-47.

11. Brown CM, Reisfeld B, Mayeno AN. Cytochromes P450: a structurebased summary of biotransformations using representative substrates. Drug Metabolism Reviews. 2008; 40 (1): 1-100.

12. Bassett CM, McCullough RS, Edel AL, Maddaford TG, Dibrov E, Blackwood DP, et al. Trans-fatty acids in the diet stimulate atherosclerosis. Metabolism. 2009; 58 (12): 1802-8.

13. Tetri LH, Basaranoglu M, Brunt EM, Yerian LM, Neuschwander-Tetri BA. Severe NAFLD with hepatic necroinflammatory changes in mice fed trans fats and a high-fructose corn syrup equivalent. American Journal of Physiololgy: Gastrointestinal and Liver Physiology. 2008; 295: G987G95.

14. Bendsen NT, Chabanova E, Thomsen HS, Larsen TM, Newman JW, Stender S, et al. Effect of trans fatty acid intake on abdominal and liver fat deposition and blood lipids: a randomized trial in overweight postmenopausal women. Nutrition and Diabetes. 2011; 1: e4.

15. Michalik L, Auwerx J, Berger JP, Chatterjee VK, Glass CK, Gonzalez FJ, et al. International Union of Pharmacology. LXI. Peroxisome proliferator-activated receptors. Pharmacology Reviews. 2006; 58 (4): 726-41.

16. Berger J, Moller DE. The mechanisms of action of PPARs. Annual Review of Medicine. 2002; 53: 409-35.

17. Donaldson K, Tran L, Jimenez LA, Duffin R, Newby DE, Mills N, et al. Combustion-derived nanoparticles: a review of their toxicology following inhalation exposure. Particle and Fibre Toxicology. 2005; 2:10.

18. Balitbangkes Departemen Kesehatan Republik Indonesia. Laporan hasil riset kesehatan dasar (Riskesdas) tahun 2010. Jakarta: Balitbangkes Depkes Republik Indonesia; 2010.

19. Khoury MJ, Bowen MS, Burke W, Coates RJ, Dowling NF, Evans JP, et al. Current priorities for public health practice in addressing the role of human genomics in improving population health. American Journal of Preventive Medicine. 2011; 40 (4): 486-93.

20. Suguro R, Wei B, Wang Y, Li R, Xiong S. In vivo antioxidant activity and its protective effects of green tea extract on acute myocardial infarction. Journal of Chinese Pharmaceutical Sciences. 2012; 22 (4): 342-7. 